\title{
Tulane
}

\author{
Tulane Economics Working Paper Series
}

\section{Inequality and Poverty under Latin America's New Left Regimes}

\author{
Darryl McLeod \\ Economics Department \\ Fordham University \\ Bronx, NY \\ mcleod@fordham.edu
}

\author{
Nora Lustig \\ Department of Economics \\ Tulane University \\ New Orleans, LA \\ nlustig@tulane.edu
}

\author{
Working Paper 1117 \\ March 2011
}

\begin{abstract}
Inequality and poverty fell sharply in many Latin American countries during a decade in which voters in ten countries chose left-leaning leaders. Are these developments related? Using data for 18 Latin American countries, this paper presents econometric evidence that social democratic regimes in Brazil and Chile were more successful at reducing inequality and poverty than the so-called populist regimes of Argentina, Bolivia, and Venezuela. Both groups implemented policies to redistribute income, but the social democratic regimes' efforts were more effective. Argentina and Venezuela started the 1990-2008 sample window with lower levels of inequality, so to some extent recent reductions in inequality are a return to "normal" levels (as estimated by fixed effects). Conversely, inequality and poverty in Brazil and Chile fell to historic lows. Second, overall terms of trade shocks were more favorable to Argentina and Venezuela, so part of the drop in inequality can be attributed to commodity price booms.
\end{abstract}

Keywords: inequality, poverty, social policy, new left, Latin America JEL: O15, P16, I32 


\title{
Inequality and Poverty under Latin America's New Left Regimes
}

\author{
Darryl McLeod and Nora Lustig
}

Version for submission; April 2011

\begin{abstract}
Inequality and poverty fell sharply in many Latin American countries during a decade in which voters in ten countries chose left-leaning leaders. Are these developments related? Using data for 18 Latin American countries, this paper presents econometric evidence that social democratic regimes in Brazil and Chile were more successful at reducing inequality and poverty than the so-called populist regimes of Argentina, Bolivia, and Venezuela. Both groups implemented policies to redistribute income, but the social democratic regimes' efforts were more effective. The left populists regimes such as Argentina and Venezuela started the 19902008 sample window with lower levels of inequality, so to some extent recent reductions in inequality are a return to "normal" levels (as estimated by fixed effects). Conversely, inequality and poverty in Brazil and Chile fell to historic lows. Moreover, overall terms of trade shocks were more favorable to Argentina and Venezuela, so part of the drop in inequality can be attributed to commodity price booms.
\end{abstract}

Key words: inequality, poverty, social policy, new left, Latin America

JEL Codes: O15, P16, 132 
Income inequality in Latin America remains high, but there are signs of progress. ${ }^{1}$ The past decade has seen inequality and poverty fall in most countries (see Figures 1 and 2 and Helwege and Birch (2007), Gasparini et al. (2008), Lustig (2009), Pinkovskiy and Sala-i-Martin (2009), CEPAL (2010), Cornia (2010), Lopez-Calva and Lustig (2010) and UNDP (2010)). ${ }^{2}$ Falling poverty and inequality, as it happens, coincides with the election of left of center governments in Argentina, Bolivia, Brazil, Chile, Ecuador, Nicaragua, Uruguay and Venezuela (see Table 1). By 2009, ten countries, accounting for two-thirds of the region's population, had left-leaning governments.

To what extent have these new regimes been responsible for reductions in inequality and poverty? Lustig (2009) and Cornia (2010) find that political regimes matter for inequality reduction. However, Lustig and McLeod (2009) find that while the so-called left populist regimes (as classified by Arnson and Perales, 2007) did reduce inequality, to some extent these reductions are a return to normal levels, where "normal" inequality is estimated by fixed effects. ${ }^{3}$ On the other hand, Brazil and Chile, reached historic lows in both inequality and poverty. Moreover, Argentina and Venezuela were recovering from economic crises and benefited from sharp increases in the price of commodities during the 2002-2008 years (see Figure 5). That is to say, unless one can control for other factors impacting inequality, one cannot conclude that it was the initiatives and policies of their governments that caused a reduction in poverty and inequality during this period. In fact, Lustig and McLeod find that the inequality-reducing impact of public spending in Argentina, Bolivia, and Venezuela becomes statistically insignificant once one controls for unobserved (fixed) effects and the commodity price boom.

This paper confirms and extends the results of Lustig and McLeod (2009) on the impact of political regimes on inequality. We reproduce and expand on the results of our previous paper 
and then test the impact of political regimes for the same 18 Latin American countries on various poverty rates during the period $1989-2008 .{ }^{4}$ We "sample" SEDLAC survey data over three year intervals taking into account intermittent surveys in many countries. ${ }^{5}$ For inequality, adding fixed effects reversed the impact of political regimes, showing so-called left-populist regimes to be less redistributive and social democratic regimes to be more effective in reducing inequality during 1999-2008, the period during which the leftist governments were voted in. For a wide range of poverty rates published by SEDLAC, the results again favor social democratic regimes. Controlling for a range of exogenous shocks and policy interventions, poverty falls consistently under these regimes.

Generally, the regression results suggest that terms of trade and growth have substantial impacts on poverty rates, as does social spending. ${ }^{6}$ Using a range of poverty measures that include the poverty gap and the poverty gap squared, these results reinforce the findings of Lustig and McLeod (2009) that the social democratic regimes in Brazil, Chile and, to a lesser extent, Uruguay have been more successful than so-called left-populist regimes in reducing poverty and inequality. In fact, the evidence for poverty reduction is robust to a range of estimation methods and poverty measures, as discussed in the next section.

Since the downward trend in inequality and poverty and the new left governments are barely a decade old, with each government group including just a handful of countries, the scope for statistical analysis is limited and many of the issues explored in this paper will not be resolved for many years. Still econometric analysis has an important role in controlling for a host of factors that may impact poverty and inequality in addition to the particular regime.

\section{Data}


Researchers are fortunate that Latin America's recent move to the left occurred just after measures of inequality greatly improved. SEDLAC's survey-based poverty and inequality indicators - computed from household survey data tabulated in a relatively uniform fashion represent a unique opportunity to test whether political regimes matter. ${ }^{7}$ Household surveys became more abundant in the 1990s, but apart from a few countries with annual surveys (Argentina and Brazil, for example), household surveys are intermittent at best. ${ }^{8}$ To deal with this problem of intermittent household surveys we follow Barro $(2000,2008)$ and sample inequality measures using three-year intervals, choosing the middle or most recent available survey in each interval. Other control variables such as per capita income and the terms of trade are three-year averages.

During 1989-2008 about 175 survey-based data points (inequality and poverty measures) are available in the SEDLAC database. To cover 18 years and 18 countries would require about 360 survey data points. Hence, about $50 \%$ of the country/years observations have no survey data. By "sampling" three-year intervals, we are able to cut the missing observations down to about $20 \%$, leaving just under 90 observations once other missing data is considered. ${ }^{9}$ Using threeyear intervals in a panel also provides a wider range of political regime measures for testing. Political regimes are measured in three ways. The first is the 0,1 dummy proxy. ${ }^{10}$ Each regime is allowed a year for its policies to begin effects, so any three year period during which a left leaning government is in office for more than one year gets a 1 and other years get a zero (see Table 1 for the first effective year of each regime). A second measure counts the number of years a given regime has been in power within a particular period (for example, if they are in power two years out of a period of three, they get a two), always skipping the initial year in office because it generally takes some time for a government to implement its own policies. A 
third regime measure, reported in the last three columns of Table 1, calculates the cumulative years the regime is in power between 1989 and 2008, again not including the year the government takes office (counting starts with the "effective year" shown in Table 1). Lustig and McLeod (2009) report results mainly for the first 0,1 dummy proxy (or the product of this dummy and some policy intervention). This paper on the other hand, uses almost exclusively the second two regime measures that also capture the intensity (years in power), or cumulative impact of a particular regime. ${ }^{11}$ The Chavez regime in Venezuela for example, has been in power for over ten years, ample time to implement and refine redistributive policies. Similarly, Chile's social democratic regime exited in March of this year after almost a decade in power. ${ }^{12}$

\section{Political Regime and Inequality}

As mentioned above, Lustig and McLeod (2009) found that political regime matters for inequality reduction. In particular, leftist regimes were found to be more redistributive than nonleftist regimes and, within the left, once one controlled for other variables and fixed effects were taken into account social democratic regimes were found to be more redistributive than so-called populist regimes. In this paper, we check the robustness of these results by using the regime measures described in the previous section and also test whether the results apply to poverty and not just inequality.

Table 2 presents estimates of how the two political regimes (populist and social democratic left) affect inequality, using the Gini coefficient as the dependent variable and per capita income as a control variable (the classic Kuznet's relationship). Various measures, such as public spending, trade and remittances are used as explanatory variables; changes in net barter terms of trade and fuel exports as a percent of merchandise trade are included as control 
variables as well. Equations 1.1 to 1.3 are panel estimates without unobserved fixed effects, equations 1.4 to 1.8 include both country and period fixed effects. Even controlling for observed and unobserved determinants of inequality, the effect of political regime can be large. The estimated cumulative effect of a social democratic regime in power for six years is a $2-3$ point reduction in the Gini coefficient, which is more or less what happened in post 2003 Chile and Brazil (using the -.4 and -.6 coefficients shown in Table 2 for eqs. 1.4, 1.5 or 1.8). Whereas overall Latin American public spending is regressive (line 3 of Table 2), social spending significantly reduces inequality. ${ }^{13}$ Note, however, that there is very little interaction with the political regime variables, suggesting that the increase in overall social spending is not the way Latin American governments have reduced inequality (see eqs. 1.5, 1.7 and 1.8, and the coefficient on the fourth line of Table 2). One possibility is that these governments may be able to better target the same amount of spending; that is, social spending became more progressive. ${ }^{14}$ Finally, equations 1.2, 1.3 and 1.6-1.8 control for a number of external influences, including the terms of trade, remittances and various sorts of exports. Terms of trade improvements tend to reduce inequality, perhaps due to the favorable impact on agriculture and rural wage rates (we return to this in the following section on poverty). Similarly, merchandise exports tend to reduce inequality; however, fuel exports increase inequality. Taken together these results suggest any shift away from fuel and mineral exports (see also Table 4 for poverty impacts) tends to reduce poverty and inequality, potentially due to the widely noted fact that mineral and fuel exports decrease the quality of governance and/or because these sectors are less labor intensive. ${ }^{15}$

Broadly, the regression results suggest a recurring pattern. Without fixed effects, socalled left populist regimes appear to reduce inequality relative to the control group of non-left, but social democratic regimes do not. With fixed effects, the impact of political regime is 
reversed: the social democratic regimes reduce inequality significantly using all three measures vis-à-vis the non-left while left populist regimes have no impact on inequality. Note also that terms of trade and the composition of trade become much more significant with the fixed effects estimates. The impact of per capita income, which does not change dramatically over this period, gets lost in the fixed effects as well. Public consumption spending remains regressive with or without fixed effects, though having a social democratic regime tempers these regressive impacts somewhat. ${ }^{16}$

Why do fixed effects reverse the impact of social democratic regimes vis-à-vis left populist regimes? The longer lived social democratic regimes are Chile and Brazil whereas the main left populist regimes are Argentina and Venezuela. The fixed effects capture the long run effect of history and institutions, slow to change determinants of inequality such as the distribution of land, racial and ethnic inequality, the composition of industry, and the full range of government policies that can increase or reduce inequality. Adding fixed effects effectively separates variables that change inequality during our 1989 to 2008 sample period, such as terms of trade and government policies, from unchanged or slow changing institutional factors. ${ }^{17}$ Hence, the observed post 2000 fall in inequality for Argentina and Venezuela can be interpreted as a return to typically lower levels of inequality for these countries. For Brazil and Chile, on the other hand, inequality fell to historic lows, partially reversing long term institutional factors that have, in the past, made inequality higher than average in these countries.

Figure 3 confirms this pattern: in both Argentina and Venezuela inequality rises and then falls back toward levels observed in the early 1990s (inequality in both countries falls after 2002 but remains higher than it was in the early 1990s). In both Chile and Brazil inequality levels ends lower than they were in the early 1990s: hence the social democratic countries appear to 
have broken with the past while Venezuela and Argentina have returned toward previously recognized lower levels of inequality. As it happens, post 2000 terms of trade trends were also much more favorable for Argentina, Venezuela and Bolivia (see Figure 5). Chile and Brazil experienced favorable movements in their terms of trade, but ones that were not nearly as dramatic. Terms of trade movements contributed to the reduction of inequality in all three groups of countries, according to the fixed effects estimates reported in Table 2 (see also Table 4 and 5 for poverty impacts). However, the windfalls for so-called left populist governments were higher than for both the social democratic regimes and for the rest of Latin America (our control group).

\section{Political Regime and Poverty}

Inequality can be reduced by redistributing income from the rich to the middle class, or by raising the share of the bottom two quintiles and in the process reducing poverty. Hence, in order to check whether left-leaning governments favor the poor, it is not enough to test their performance vis-à-vis inequality. Using the range of poverty estimates provided by SEDLAC ${ }^{18}$ allows us to explore how political regimes, policies and external shocks affect various members of the bottom strata. Figures 2 and 6 show the different poverty rates SEDLAC computes for the countries in our sample. All of the poverty measures roam the bottom half of the income distribution (only Bolivia, Honduras and El Salvador frequently have moderate poverty rates over 50\%, though in Mexico and Venezuela moderate poverty has been over $60 \%$ during crisis years). In most Latin American countries, the so-called extreme, or indigence poverty rate generally reflects living standards in the bottom quintile (except for Bolivia and Honduras where extreme poverty lines roam the $2^{\text {nd }}$ quintile). 
Table 4 regresses the log change in moderate and extreme poverty (headcount) on a similar set of variables used in Table 2, where the dependent variables are the Gini coefficients. Using changes makes fixed effects dissappear. In the case of poverty (as opposed to inequality), fixed effects did not change the results so they can be left out. The reason for this is because the initial level of poverty is not key to the result (while it is for inequality). The results for changes in moderate and extreme poverty show a pattern similar to that for the fixed effects regressions reported as eqs. 1.4 to 1.8 in Table 2. Social democratic regimes tend to be more effective than left populist regimes in reducing both poverty rates. ${ }^{19}$ Again changes in social spending reduces poverty among people living in both moderate and extreme poverty, but has a larger impact on the latter, as expected. Inflation also raises both poverty rates, again hitting the bottom quintile hardest (though low poverty rates tend to make log changes in poverty rates larger, see Lustig and McLeod, 1997, Appendix 3A). Remittances, manufacturing exports, and especially terms of trade changes reduce poverty, though manufacturing exports only impact extreme poverty. Raising the minimum wage increases moderate poverty which suggests that the negative effect on employment may dominate over the positive so-called "light-house" effect. $^{20}$

Table 5 provides additional tests, calculating the impact of political regimes on moderate poverty using the same approach used for the Gini coefficient in Table 3 and in Lustig and McLeod (2009). The results for poverty rates are more robust in the sense that the signs and significance of the regime impacts do not depend on the estimation method (i.e., the use of fixed effects). The key difference between the Table 3 results for the Gini coefficient and this table's for the level of moderate poverty is that with or without fixed effects, social democratic regimes tend to be more effective than left populist regimes (and non-left) in reducing poverty and that this outcome is cumulative: the longer the social democratic regime is in power, the larger the 
reduction in poverty. Again, there is a lot of interaction between the terms of trade and the political regime measure. Note that comparing equation 5.2 to equation 5.5 and adding both fixed effects and the terms of trade seems to reduce the impact of social democratic regimes (the t-statistic for cumulative years in power is not significant at the $5 \%$ level). However, this result seems to be largely due to Uruguay, since equation 5.5a drops Uruguay and the political regime variable rises from .05 to .07 and becomes highly significant. Similarly, equations 5.6 and 5.7 control for a range of other policies and events: equation 5.7 drops the terms of trade, again raising the size of the intervention coefficient. Lustig and McLeod (2009) show that terms of trade windfalls have a greater effect under social democratic regimes, one interpretation of this interaction is that these regimes at redistributing terms of trade windfalls. Finally, equations 5.3, 5.6 and 5.7 replace social spending with the share of social spending in total public consumption. Since overall public spending in Latin America is regressive, reallocating fiscal spending to social programs (as defined by CEPAL) reduces poverty faster than increasing social spending alone. Inflation and the minimum wage also have more robust impacts on moderate poverty (as opposed to overall inequality). As in Table 4, for changes in moderate poverty, the level of the minimum wage tends to increase moderate poverty with or without fixed effects. Inflation also has a robust negative impact on moderately poor households.

Finally, Table 6 tests a single new specification across the full range of poverty measures provided by the SEDLAC database. Instead of using first differences or fixed effects, we condition on the initial level of each poverty measure (picking up the fixed effects). The last row of Table 6 summarizes the mean of each poverty measure for this group of countries (Uruguay is dropped, though the main results are not affected by adding it). The lowest mean poverty rate is $14 \%$ for extreme poverty, followed by $23 \%$ for the $\$ 2.50 /$ day poverty line. Both the $\$ 4 /$ day line 
and the moderate poverty line average about $40 \%$ (though they are computed using both the same and different poverty lines in each country). In terms of the incidence of poverty (the number of poor over the total population), if anything social democratic regimes reduce poverty in the bottom quintile more than for the second quintile (captured by eqs. 6.2 and 6.3). Public spending on social programs also seems to reduce the headcount ratio, even those below the lowest "extreme" poverty line, though the impact on the more uniform $\$ 2.50$ /day poverty line is not significant. Finally, both the terms of trade and overall economic growth (per capita income) seem to be reaching the poorest groups.

The poverty gap and the poverty gap squared measure not only the number of poor below each poverty line but also the depth of poverty (or average incomes). The poverty gap squared places more weight on the poorest of the poor. Surprisingly, political regime still matters even at the lower $\$ 2.50$ /day poor groups, but social spending does not seem to increase the average income of the poor or the poorest (note the impact of social spending becomes insignificant). If anything, the impact of economic growth and terms of trade changes increase when we focus on the average incomes of the poor and the poorest. However, the evidence presented in Table 6 suggests that the poorest groups have not only benefited from cumulative rule by left populist governments, but may even have lost out a bit during the time period in the countries considered here.

The results for poverty rates in Tables 4-6 reinforce the findings in Lustig and McLeod (2009) that political regimes, growth and terms of trade shocks matter for poverty and inequality. Taken as a whole however, these results suggest left populist governments have been less successful than social democratic governments in reducing poverty. Exactly how social democratic governments have helped the poor needs to be clarified. Social spending seems to be 
important, but it is not the entire story. Social democratic governments appear to better target existing levels of spending, and reallocating spending toward social programs has a strong impact. Future research along these lines must test a number of other measures that may be helping the poorest groups under social democratic regimes: access to eduction, targeted conditional cash transfers and labor intensive exports (both Brazil and Chile are relatively successful exporters of manufactures, for example).

\section{Conclusion}

To summarize, the panel estimates for 18 countries with adequate data for the period 1989 to 2008 suggest political regimes do matter for inequality outcomes. However, the results for so-called populist and social democratic regimes are different: even controlling for the commodity price boom, poverty and inequality fell faster under the social democratic regimes in Brazil, Chile and -to a lesser extent- Uruguay. The inequality and poverty-reducing impact of the left-populist regimes in Argentina, Bolivia and Venezuela vanishes once one controls for unobserved effects and the commodity price boom. Historically, Argentina and Venezuela had lower levels of inequality and poverty (especially extreme poverty) than other Latin American countries, so a return to "normal" levels of inequality also helps explain part of the sharp post 2002 fall in inequality both countries experienced (as measured by the Gini coefficient, and in particular when considering the extreme poverty rate, see Figures 2, 3 and 4). Further analysis should allow us to separate out the impact of public policy (via education spending for example), but the evidence suggests that social democratic regimes have been able to reduce poverty faster than left populist regimes (as measured by a wide range of poverty measures). Even controlling for other factors, the evidence for social democratic regimes is more conclusive: they have been 
more effective than non-left and left populist governments in reducing poverty and inequality, although exactly how they have done this is a topic for further research.

Having said this, should so-called left populist regimes be given credit for reducing inequality to pre-crisis or historic norms? They should. Once inequality increases, it may well be difficult to return to pre-crisis levels. The governments of Argentina and Venezuela deserve credit for reducing inequality and poverty back toward 1990 levels. However, there is a difference between returning to historic low levels and reducing poverty and inequality to historic lows, as Chile and Brazil have done. 


\section{References}

Acemoglu, Daron, Georgy Ergorov, and Konstantin Sonin (2010). “A Political Theory of Populism”, MIT, mimeo, August, Cambridge, MA. ideas.repec.org/e/pso47.html

Arnson, Cynthia with José Raúl Perales (2007). The 'New Left' and Democratic Governance in Latin America. Washington, D.C.: Woodrow Wilson International Center for Scholars, August. www.wilsoncenter.org/topics/pubs/NewLeftDemocraticGovernance.pdf .

Barro, Robert (2000). "Inequality and Growth in a Panel of Countries", Journal of Economic Growth, 5(1). 5-32.

Barro, Robert (2008). "Inequality and Growth Revisited”, Working Paper Series on Regional Economic Integration No. 11, Asian Development Bank, Philippines, January. http://aric.adb.org/pdf/workingpaper/WP11_\%20Inequality_and_Growth_Revisited.pdf

Brollo, Fernanda, Tommaso Nannicini, Roberto Perotti and Guido Tabellini (2010). "The Political Resource Curse”, NBER Working Paper 15705, www.nber.org/papers/w15705. CEPAL (2010). Hora de la igualdad: brechas por cerrar, caminos por abrir. Santiago, Chile. Collier, Paul \& Goderis, Benedikt (2008). "Commodity Prices, Growth, and the Natural Resource Curse: Reconciling a Conundrum", MPRA Paper 17315, University Library of Munich, Germany.

Cornia, Giovanni Andrea (2010). “Income Distribution under Latin America's New Left Regimes", Journal of Human Development and Capabilities, Vol. 11, \#1, February.

Gasparini, Leonardo, Guillermo Cruces and Leopoldo Tornarolli (2008). "Is income inequality in Latin America falling?”, CEDLAS, Universidad Nacional de La Plata, August version. 
Helwege, Ann and Melissa B.L. Birch (2007). "Declining Poverty in Latin America? A Critical Analysis of New Estimates by International Institutions", September, Tufts University, Tufts University Medford MA 02155, USA http://ase.tufts.edu/gdae

Huber, Evelyn, Thomas Mustillo and John D. Stephens (2008). "Politics of social spending in Latin America", The Journal of Politics (70: 2)

López-Calva, Luis Felipe and Nora Lustig, eds. (2010). Declining Inequality in Latin America: A Decade of Progress?, Brookings Institution Press and UNDP, Washington D.C.

Lustig, Nora (2009). Poverty, Inequality and the New Left in Latin America, Washington, D.C.: Woodrow Wilson International Center for Scholars, Latin American Program, October. and Darryl McLeod (1997). "Minimum Wages and Poverty in Developing Countries:

Some Empirical Evidence" in Edwards, Sebastian and Nora Claudia Lustig eds., Labor Markets in Latin America, Brookings Institution Press, Washington D.C. and Darryl McLeod. 2009. “Are Latin America’s New Left Regimes Reducing Inequality Faster? Addendum to Nora Lustig, 'Poverty, Inequality, and the New Left in Latin America." Washington: Woodrow Wilson International Center for Scholars (July). Pinkovskiy, Maxin and Xavier Sala-i-Martin (2009). "Parametric Estimations Of The World Distribution of Income", NBER Working Paper 15433, Boston, Ma, www.nber.org/papers/w15433.

Roberts, Kenneth (1995). "Neoliberalism and the Transformation of Populism in Latin America: The Peruvian Case", World Politics. 48:1 p. 88.

Robinson, James (2010). “The Political Economy of Redistributive Policies," in Luis F LópezCalva and Nora Lustig (eds.), Declining Inequality in Latin America: a Decade of Progress? Brooking Institute Press, and UNDP, Washington D.C. 
SEDLAC (Socio-Economic Database for Latin America and the Caribbean) accessed June, 2009, the World Bank, CEDLAS, La Plata, Argentina \& Washington DC www.depeco.econo.unlp.edu.ar/cedlas/sedlac/.

UNDP (2010). Actuar sobre el futuro: Romper con la transmision intergeneracional de la desigualdad, First Regional Human Development Report, Regional Bureau for Latin American and the Caribbean, http://www.idhalc-actuarsobreelfuturo.org/site/index.php. 


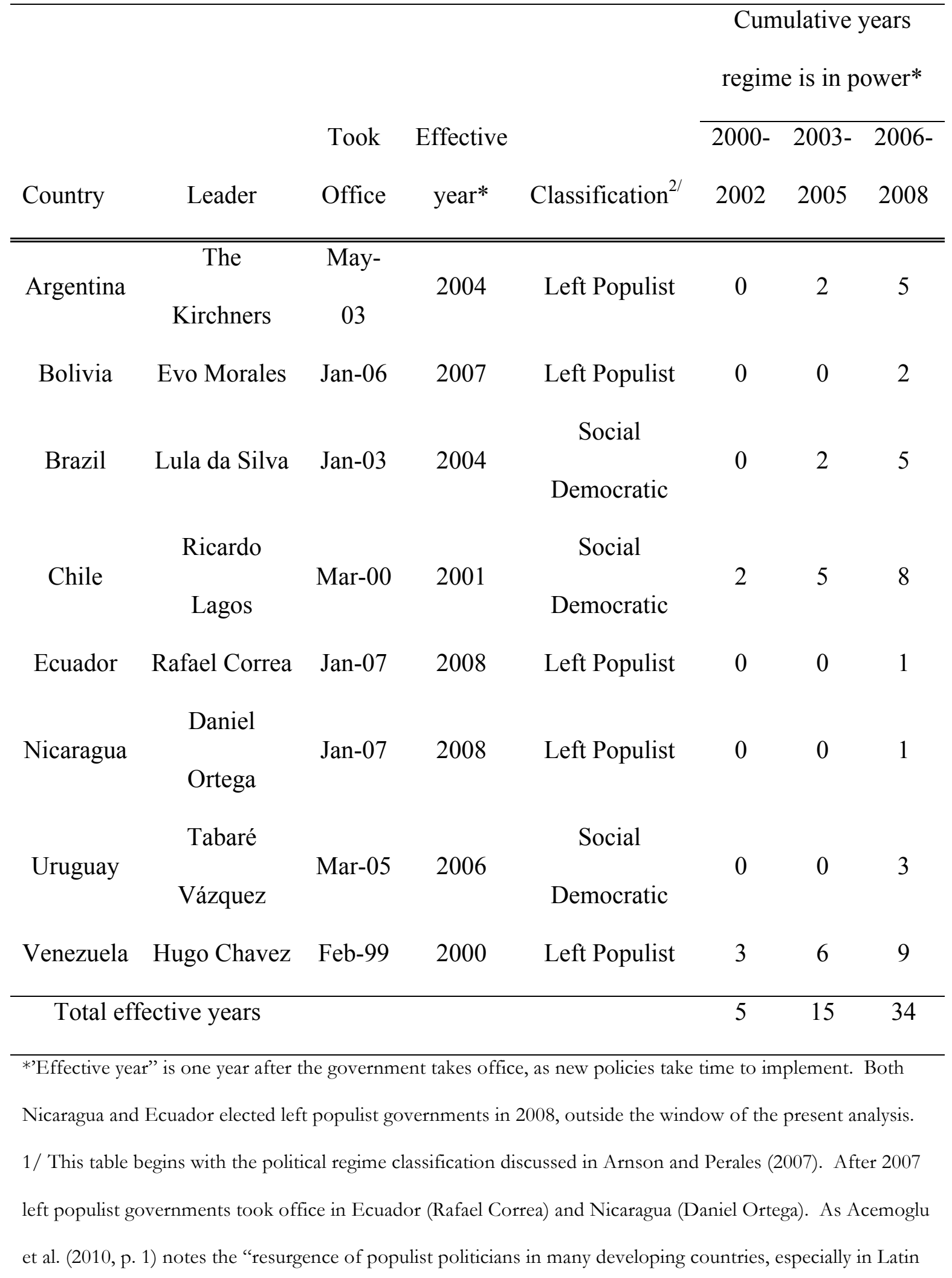


America. Hugo Chavez in Venezuela, the Kirchners in Argentina, Evo Morales in Bolivia, Alan Garcia in Peru, and Rafael Correa in Ecuador are examples of politicians that "use the rhetoric of aggressively defending the interests of the common man against the privileged elite." Unfortunately, Nicaragua could not be included among the left populist countries in the regression analysis because its data ends in 2006. El Salvador and Paraguay were not included among the left governments because of similar reasons. 
Table 2: Determinants of Latin American Inequality 1990-2008 (as meas ured by the Gini coefficient) ${ }^{2 /}$

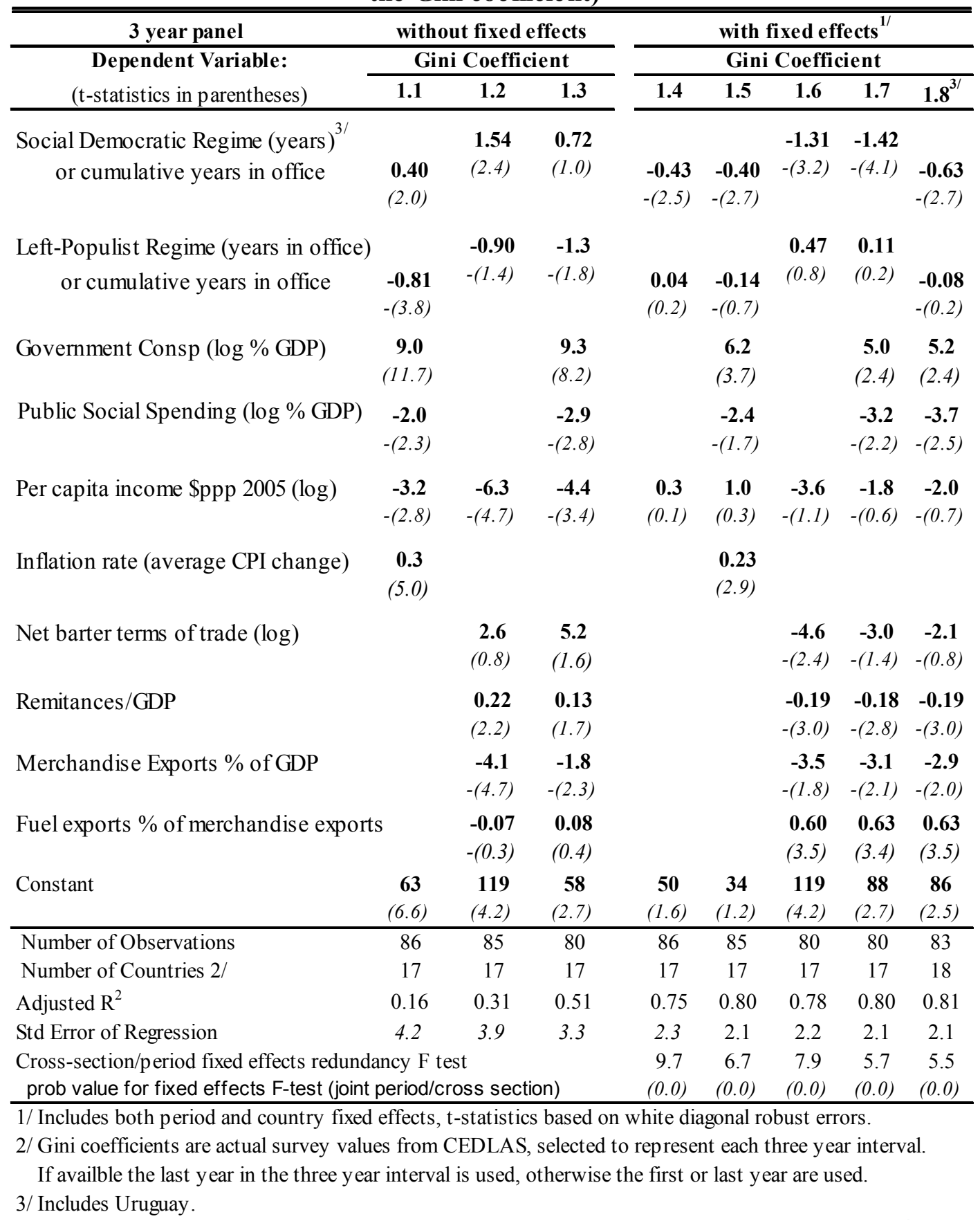


Table 3: Fixed Effects from Table 2 Regressions

\begin{tabular}{lccc}
\hline From Table 2: & eq. 1.8 & eq. 1.4 & eq. 1.7 \\
\hline \hline Argentina & -3.17 & -4.50 & -3.96 \\
Brazil & 1.88 & 6.36 & 2.11 \\
Bolovia & 3.45 & 4.94 & 3.10 \\
Chile & 7.44 & 2.42 & 7.91 \\
Colombia & -1.25 & 2.63 & -1.51 \\
Costa Rica & -1.88 & -5.69 & -2.25 \\
Ecuador & 0.36 & 3.94 & 0.45 \\
El Salvador & -1.22 & -1.68 & -1.17 \\
Guatemala & 0.24 & 1.50 & 0.34 \\
Honduras & 2.88 & 2.35 & 2.99 \\
Mexico & 1.96 & -0.68 & 1.67 \\
Nicaragua & -2.47 & -1.15 & -2.27 \\
Panama & 0.71 & 2.39 & 0.66 \\
Paraguay & 4.95 & 2.99 & 5.10 \\
Peru & -5.14 & -3.13 & -5.01 \\
Domican Republic & -0.84 & -3.44 & -0.83 \\
Venezuela & -8.78 & -8.43 & -9.37 \\
Uruguay' & -4.36 & & \\
Period Fixed Effects & & & \\
\hline 1988-90 & -2.08 & -0.28 & -2.14 \\
1991-93 & -2.46 & -1.24 & -2.44 \\
1994-96 & -0.18 & 0.38 & -0.13 \\
1997-99 & 1.14 & 0.76 & 1.19 \\
2000-02 & 0.33 & 0.75 & 0.42 \\
2003-05 & 1.33 & 0.37 & 1.40 \\
2006-08 & 1.93 & -0.74 & 1.70 \\
\hline & & & \\
\hline
\end{tabular}


Table 4: Changes in national poverty line poverty rates for 16 Latin American Countries

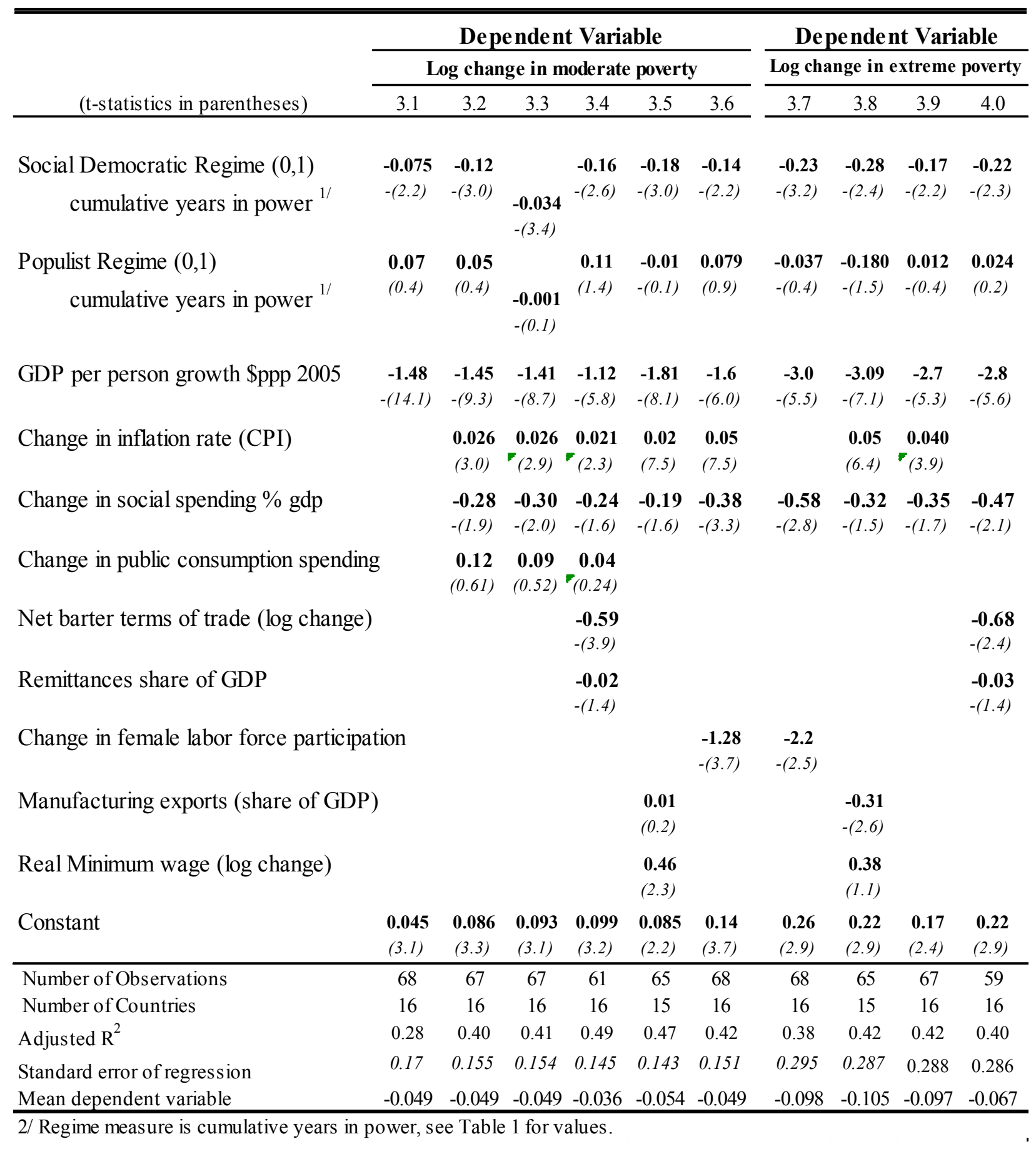


Table 5: Determinants of Moderate poverty $1990-2008^{2 /}$

\begin{tabular}{|c|c|c|c|c|c|c|c|c|}
\hline \multirow{3}{*}{$\begin{array}{c}3 \text { year panel } \\
\text { Dependent Variable: } \\
\text { (t-statistics in parentheses })\end{array}$} & \multicolumn{3}{|c|}{ without fixed effects } & \multicolumn{5}{|c|}{ with fixed effects ${ }^{1 /}$} \\
\hline & \multicolumn{3}{|c|}{ Log of Moderate Poverty } & \multicolumn{5}{|c|}{$\log$ of moderate poverty rate } \\
\hline & 5.1 & $5.2^{3 /}$ & 5.3 & 5.4 & $5.5^{3 /}$ & $5.5 \mathrm{a}$ & 5.6 & 5.7 \\
\hline Social Democratic Regime & -0.11 & -0.09 & -0.11 & -0.04 & -0.05 & -0.07 & -0.06 & -0.08 \\
\hline cumulative years in power & $-(5.5)$ & $-(3.4)$ & $-(3.9)$ & $-(3.3)$ & $-(1.7)$ & $-(2.7)$ & $-(2.7)$ & $-(4.5)$ \\
\hline Left-Populist Regime (years in & 0.05 & 0.07 & 0.02 & 0.06 & 0.06 & 0.03 & 0.05 & 0.02 \\
\hline cumulative years in power & $(1.5)$ & $(2.3)$ & $(0.8)$ & $(1.0)$ & $(1.7)$ & $(0.9)$ & $(1.5)$ & $(0.6)$ \\
\hline \multirow[t]{2}{*}{ Per capita income \$ppp 2005 (log) } & -0.34 & -0.3 & -0.25 & -1.1 & -0.6 & -0.8 & -0.5 & -0.6 \\
\hline & $-(3.2)$ & $-(2.3)$ & $-(2.7)$ & $(5.7)$ & $-(2.3)$ & $-(3.1)$ & $-(1.5)$ & $-(1.8)$ \\
\hline \multirow[t]{2}{*}{ Public Social Spending (log \% GDP) } & & -0.24 & & & -0.15 & -0.15 & & \\
\hline & & $-(2.4)$ & & & $-(1.8)$ & $F_{-}(1.8)$ & & \\
\hline \multirow[t]{2}{*}{ Change in CPI Inflation } & & 0.05 & 0.06 & & 0.05 & 0.04 & 0.04 & 0.04 \\
\hline & & $(2.3)$ & $(2.0)$ & & $(2.2)$ & $(2.4)$ & $(2.5)$ & $(2.5)$ \\
\hline \multirow[t]{2}{*}{ Net barter terms of trade $(\log )$} & & -0.63 & & & -0.52 & -0.28 & -0.30 & \\
\hline & & $-(2.6)$ & & & $F_{-}(2.8)$ & $F_{-(1.7)}$ & $-(2.1)$ & \\
\hline \multirow[t]{2}{*}{ Log real minum wage rate } & & 0.49 & 0.72 & & 0.40 & 0.57 & 0.41 & 0.53 \\
\hline & & $(2.4)$ & (3.6) & & $(1.5)$ & $(2.1)$ & (1.9) & $(2.5)$ \\
\hline Share of social spending as $\%$ if total & & & -0.13 & & & & -0.26 & -0.25 \\
\hline government cons spending (WDI) & & & $-(1.6)$ & & & & $-(2.4)$ & $-(2.5)$ \\
\hline \multirow[t]{2}{*}{ Debt service as $\%$ of exports } & & & 0.19 & & & & 0.09 & 0.08 \\
\hline & & & $(3.1)$ & & & & $(2.2)$ & $(2.0)$ \\
\hline \multirow[t]{2}{*}{ Constant } & 6.6 & 7.0 & 2.1 & 13 & 10 & 9.8 & 7.0 & 6.0 \\
\hline & (7.3) & (3.6) & (1.6) & $(5.7)$ & (4.4) & $(4.6)$ & $(2.8)$ & $(2.3)$ \\
\hline Number of Observations & 88 & 81 & 75 & 81 & 81 & 75 & 75 & 75 \\
\hline Number of Countries $^{2 /}$ & 17 & 17 & 16 & 16 & 17 & 16 & 16 & 16 \\
\hline Adjusted $\mathrm{R}^{2}$ & 0.23 & 0.41 & 0.48 & 0.81 & 0.87 & 0.88 & 0.89 & 0.89 \\
\hline F-test for country fixed effects ${ }^{1 /}$ & & & & 16 & 21.3 & & 17.8 & 17.1 \\
\hline F-test for country period fixed effects & & & & 0.83 & 2.2 & & & \\
\hline Std Error of Regression & 0.36 & 0.33 & 0.29 & 0.17 & 0.15 & 0.14 & 0.13 & 0.13 \\
\hline Mean dependent variable & 3.6 & 3.6 & 3.7 & 3.7 & 3.6 & 3.7 & 3.7 & 3.7 \\
\hline
\end{tabular}

1/ F-tests for country (not period) fixed effects always ignificant at 1\%, t-statistics use white diagonal robust errors.

2/ Moderate poverty raes are survey values from CEDLAS, selected to represent each three year interval.

3/ Uruguay included in 5.5 but not 5.5 a. 
Table 6: Initial poverty level estimates for a range of poverty lines and measures

\begin{tabular}{|c|c|c|c|c|c|c|c|c|}
\hline \multirow{3}{*}{$\begin{array}{c}\text { Dependent Variable: } \\
\text { (t-statistics in parentheses) }\end{array}$} & \multicolumn{4}{|c|}{ Log Headcount (poverty rate) } & \multirow{2}{*}{\multicolumn{2}{|c|}{$\frac{\text { Poverty Gap }}{2.5 / \text { day } \$ 4 / \text { day }}$}} & \multicolumn{2}{|c|}{ Gap Squared } \\
\hline & \multicolumn{4}{|c|}{$\$ 2.5 /$ day $\$ 4 /$ day Moderate Extreme } & & & \multirow{2}{*}{$\frac{2.5 / \text { day }}{6.7}$} & \multirow{2}{*}{$\frac{\$ 4 / \text { day }}{6.8}$} \\
\hline & 6.1 & 6.2 & 6.3 & 6.4 & 6.5 & 6.6 & & \\
\hline \multirow{2}{*}{$\begin{array}{l}\text { Social Democratic Regime } \\
\text { cumulative years in power }\end{array}$} & -0.11 & -0.07 & -0.09 & -0.10 & -0.12 & -0.09 & -0.15 & -0.11 \\
\hline & $-(4.5)$ & $-(4.6)$ & $-(6.7)$ & $-(5.1)$ & $-(4.1)$ & $-(4.5)$ & $-(4.0)$ & $-(4.2)$ \\
\hline \multirow{2}{*}{$\begin{array}{l}\text { Left-Populist Regime (years in } \\
\text { cumulative years in power }\end{array}$} & 0.09 & 0.07 & 0.06 & 0.05 & 0.11 & 0.09 & 0.11 & 0.10 \\
\hline & $(2.6)$ & $(2.7)$ & (1.6) & (1.3) & $(2.6)$ & $(2.7)$ & $(2.4)$ & $(2.6)$ \\
\hline \multirow[t]{2}{*}{ Per capita income \$ppp 2005 (log) } & -0.35 & -0.23 & -0.16 & -0.33 & -0.38 & -0.32 & -0.35 & -0.36 \\
\hline & $-(4.6)$ & $-(4.4)$ & $-(3.0)$ & $-(3.1)$ & $-(4.2)$ & $-(4.4)$ & -3.11 & $-(4.3)$ \\
\hline \multirow{2}{*}{ Public Social Spending (log \% GDP) } & -0.10 & -0.11 & -0.13 & -0.24 & -0.04 & -0.09 & 0.10 & -0.05 \\
\hline & $-(1.2)$ & $-(1.8)$ & $-(2.6)$ & $-(2.7)$ & $-(0.5)$ & $-(1.3)$ & $(0.9)$ & $-(0.6)$ \\
\hline \multirow[t]{2}{*}{ Net barter terms of trade (log) } & -0.38 & -0.26 & -0.34 & -0.51 & -0.48 & -0.38 & -0.58 & -0.44 \\
\hline & $-(1.8)$ & $-(1.9)$ & $-(3.1)$ & $-(2.6)$ & $-(1.9)$ & $-(2.0)$ & $-(2.0)$ & $-(2.0)$ \\
\hline \multirow[t]{2}{*}{ Initial Poverty level circa 1990} & 0.62 & 0.73 & 0.76 & 0.73 & 0.68 & 0.72 & 0.83 & 0.67 \\
\hline & $(5.6)$ & $(6.1)$ & (11.6) & (11.5) & (7.4) & $(6.5)$ & $(6.9)$ & (7.1) \\
\hline \multirow[t]{2}{*}{ Constant } & 6.3 & 4.4 & 4.1 & 6.4 & 6.4 & 5.5 & 5.3 & 6.0 \\
\hline & (4.6) & (4.3) & $(5.4)$ & $(4.8)$ & $(4.1)$ & $(4.5)$ & $(2.9)$ & (4.3) \\
\hline Number of Observations & 84 & 84 & 84 & 84 & 84 & 84 & 85 & 84 \\
\hline Number of Countries ${ }^{2 /}$ & 17 & 17 & 17 & 17 & 17 & 17 & 17 & 17 \\
\hline Adjusted $\mathrm{R}^{2}$ & 0.70 & 0.73 & 0.69 & 0.73 & 0.70 & 0.72 & 0.63 & 0.70 \\
\hline Std Error of Regression & 0.27 & 0.19 & 0.21 & 0.35 & 0.34 & 0.26 & 0.41 & 0.30 \\
\hline Mean dependent variable & 23.4 & 40.4 & 39.3 & 14.2 & 10.2 & 18.4 & 6.5 & 11.5 \\
\hline
\end{tabular}


Figure 1 Annual percentage change in the Gini coefficient, by type of government: $2003-2006$

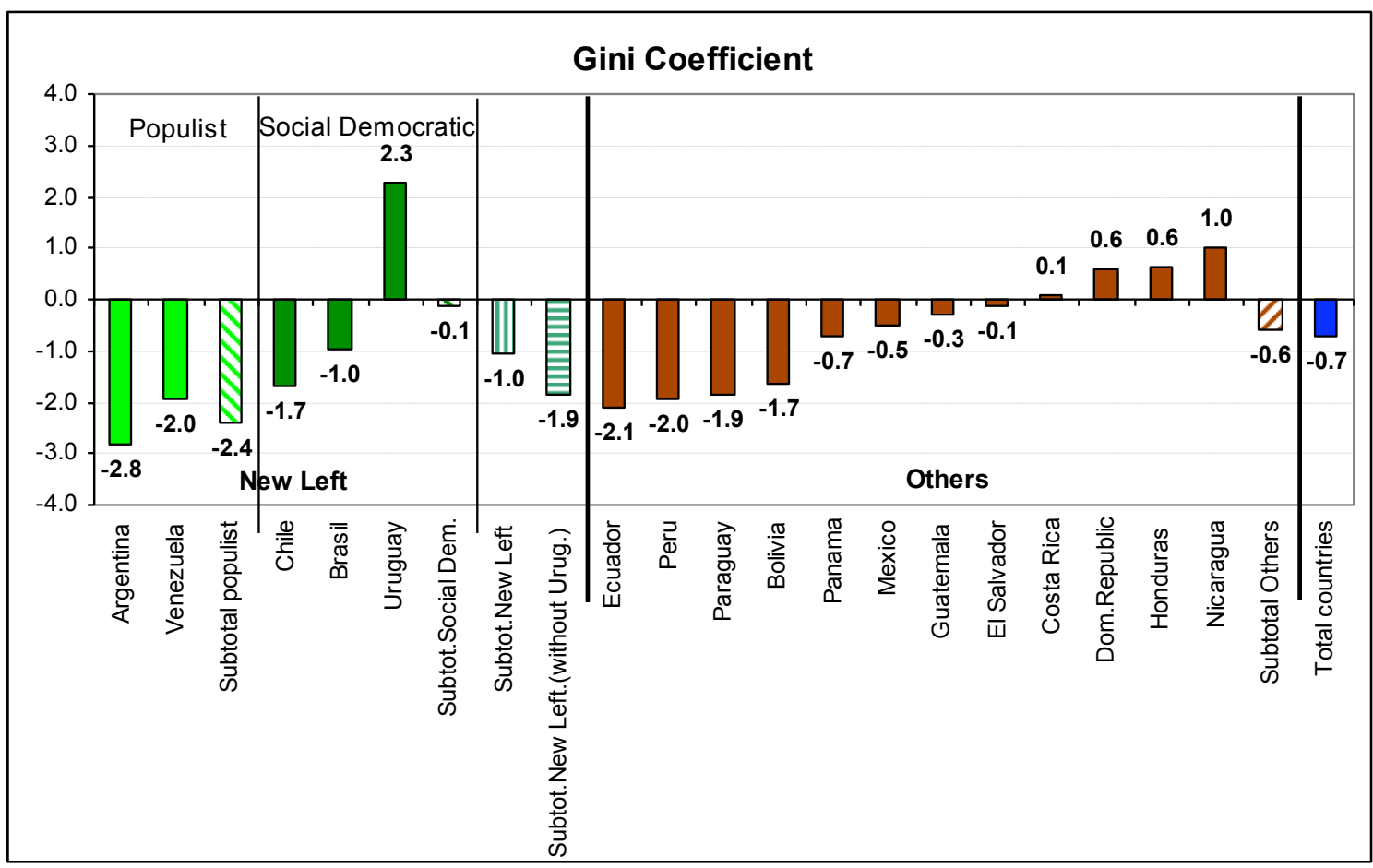

Source: Lustig (2009). Notes: Data for Argentina and Uruguay are for urban areas only. Each country's urban population represents more than 80 percent of the total population. The annual percentage change in the Gini coefficient for each country is equal to the difference between the Gini in 2006 (or closest available year) and the Gini in 2003 (or closest available year) divided by 3 (or the corresponding number of years). The changes by groups of countries are calculated as the simple average of the annual percentage change for each country belonging to the corresponding group. The percentage change in inequality refers to changes from 2003 to 2006, except in cases where data were not available for those years. For El Salvador the change is calculated from 2003 to 2005; for Guatemala it is calculated from 2000 to 2006; for Mexico it is calculated from 2002 to 2006; for Nicaragua it is from 2001 to 2005, and for Uruguay it is from 2005 to 2006. The period of 2003-2006 was selected because it included the most number of 
observations for poverty and inequality for the maximum number of countries under leftist governments. However, the years that the leftist governments were in power in each country varies: the new left has governed since 2003 in Argentina and Brazil, since 2000 in Chile, since 2005 in Uruguay, and since 1999 in Venezuela. Using the bootstrap method, the author tested whether differences between Gini coefficients between a specified year and the year immediately prior were statistically significant. Statistical significance was determined at a 95 percent level and with 100 replications. Results are presented in Table A.5 of Lustig (2009). 
Figure 2: After decades of no progress, Latin American Poverty Rates fall sharply after 2004 (share of population using national CEPAL poverty)

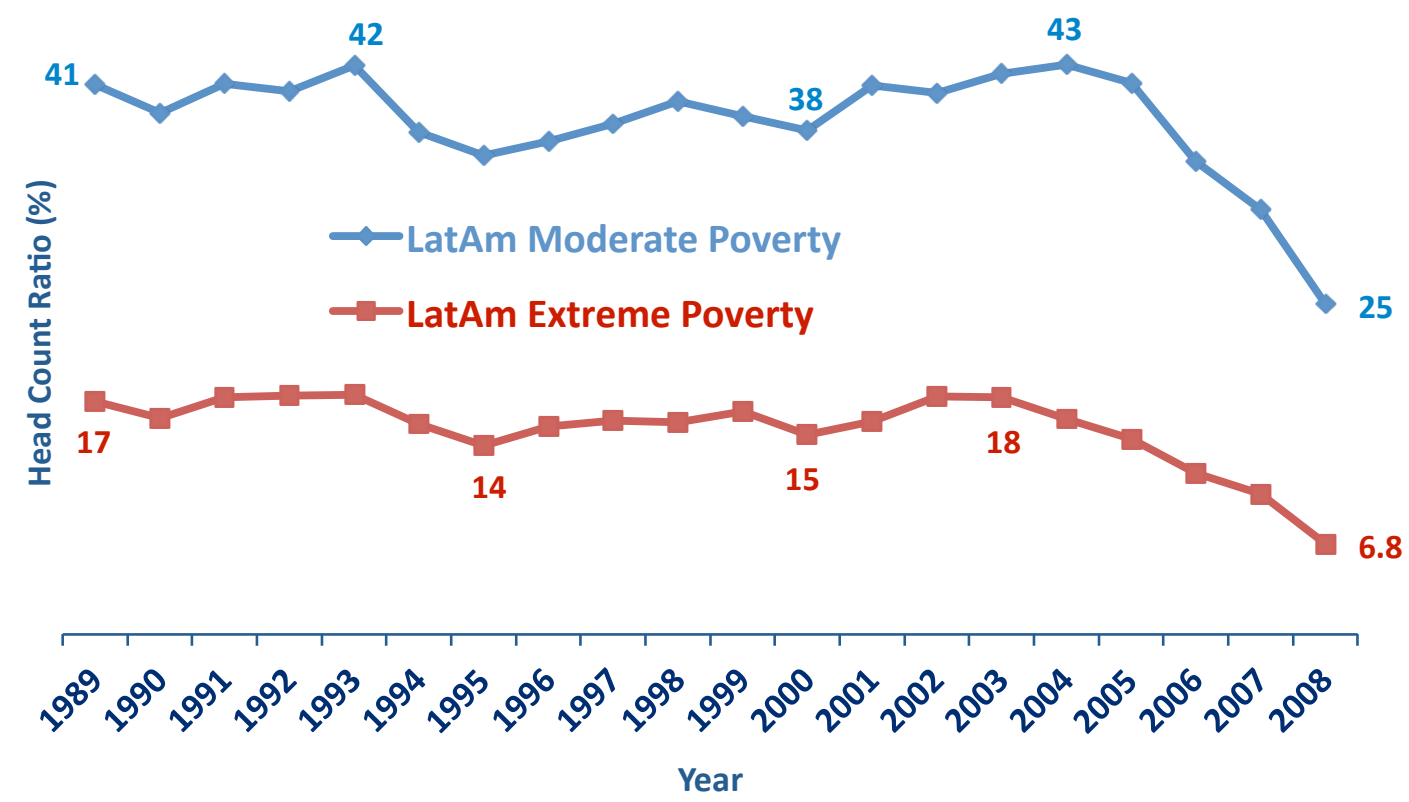

Source: SEDLAC/CEDLAS World Bank, 2009, downloaded January 2010. author's population weighted average of national poverty rates: country composition changes over time, so this is a rough estimate of poverty trends. 
Figure 3: Inequality rises and then falls in Argentina and Venezuela
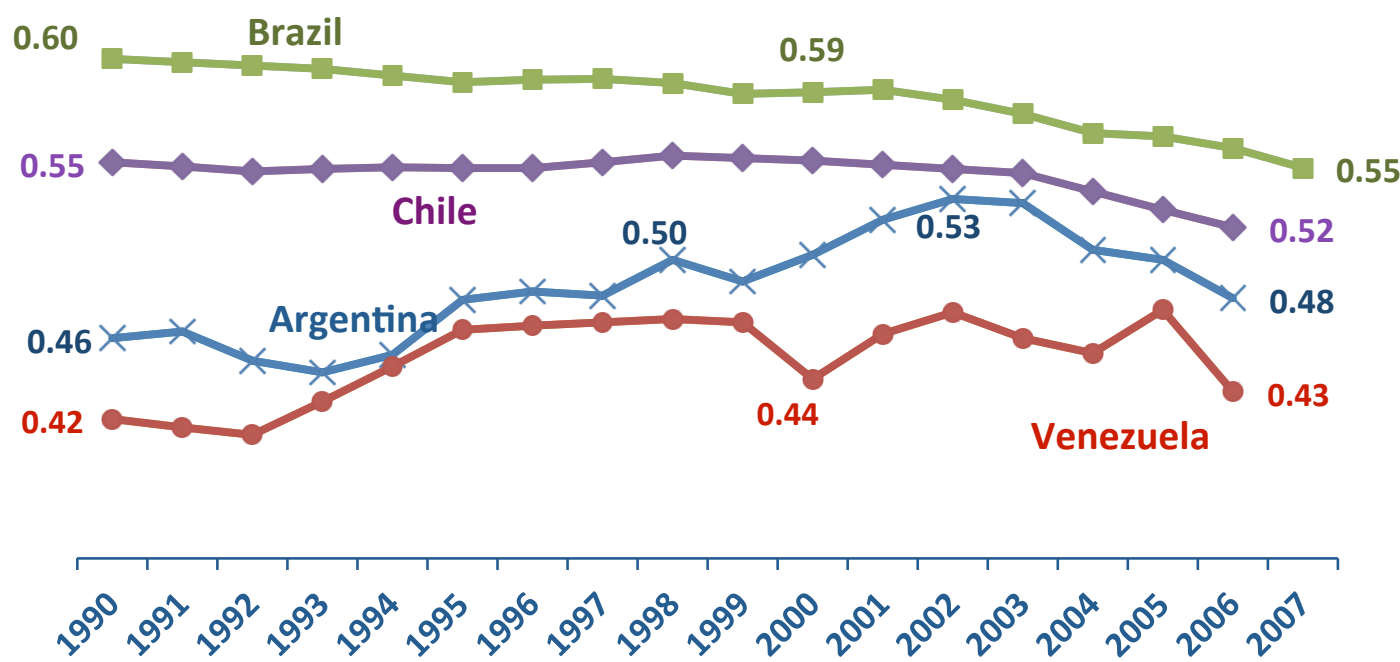

Source: SEDLAC/CEDLAS World Bank data downloaded July, 2009 Argentina is for urban areas only.

Figure 4a Extreme poverty in Argentina , Brazil, Chile and Venezuela

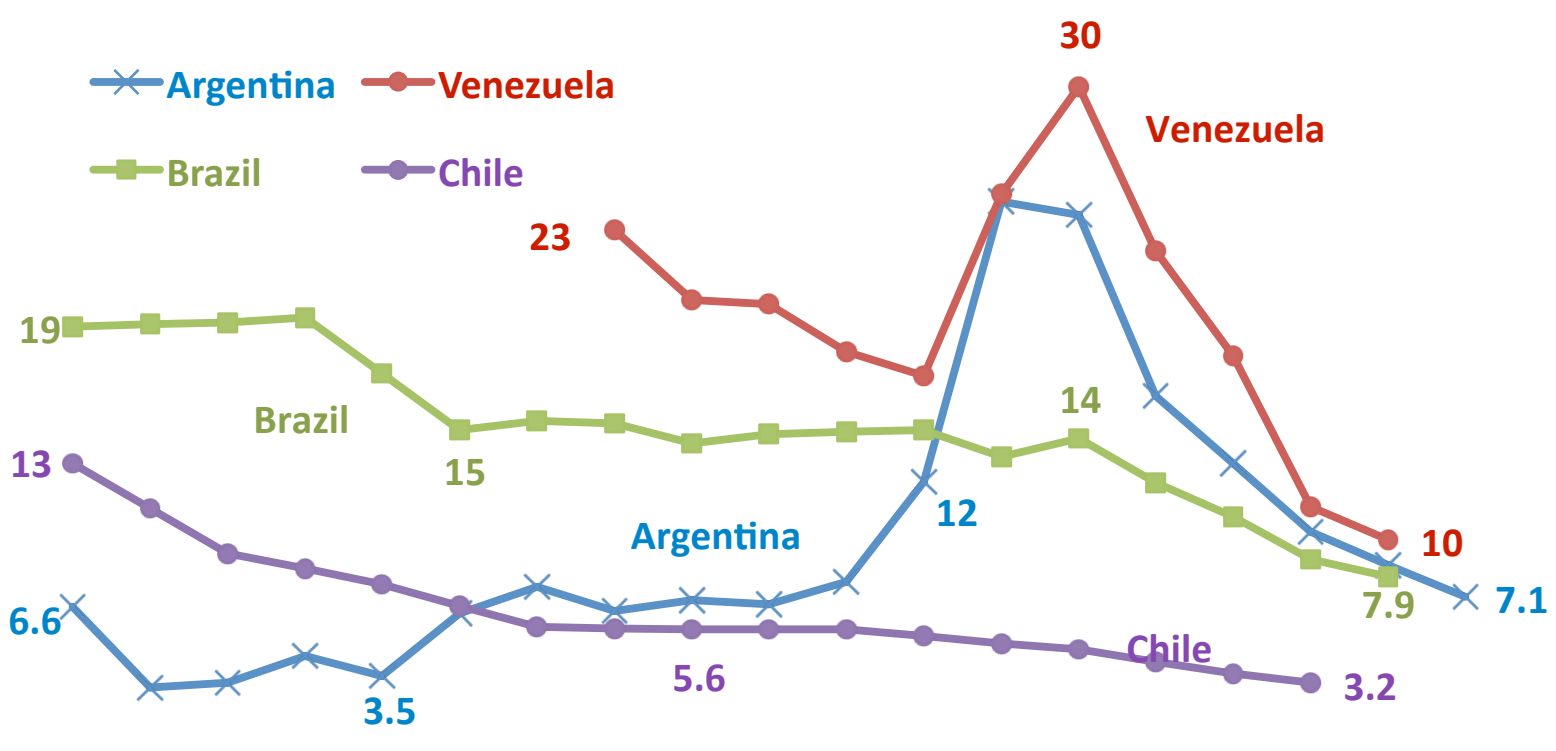

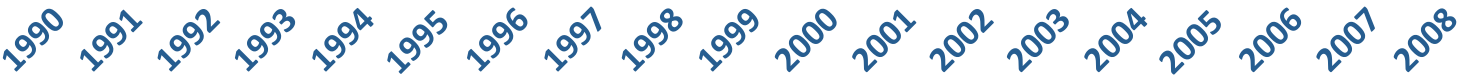
Source: SEDLAC/CEDLAS World Bank data downloaded July, 2009. Argentina is for urban areas only. 
Figure 4b: Moderate Poverty rates in Argentina, Brazil, Chile \& Venezuela (share population below national CEPAL poverty line)
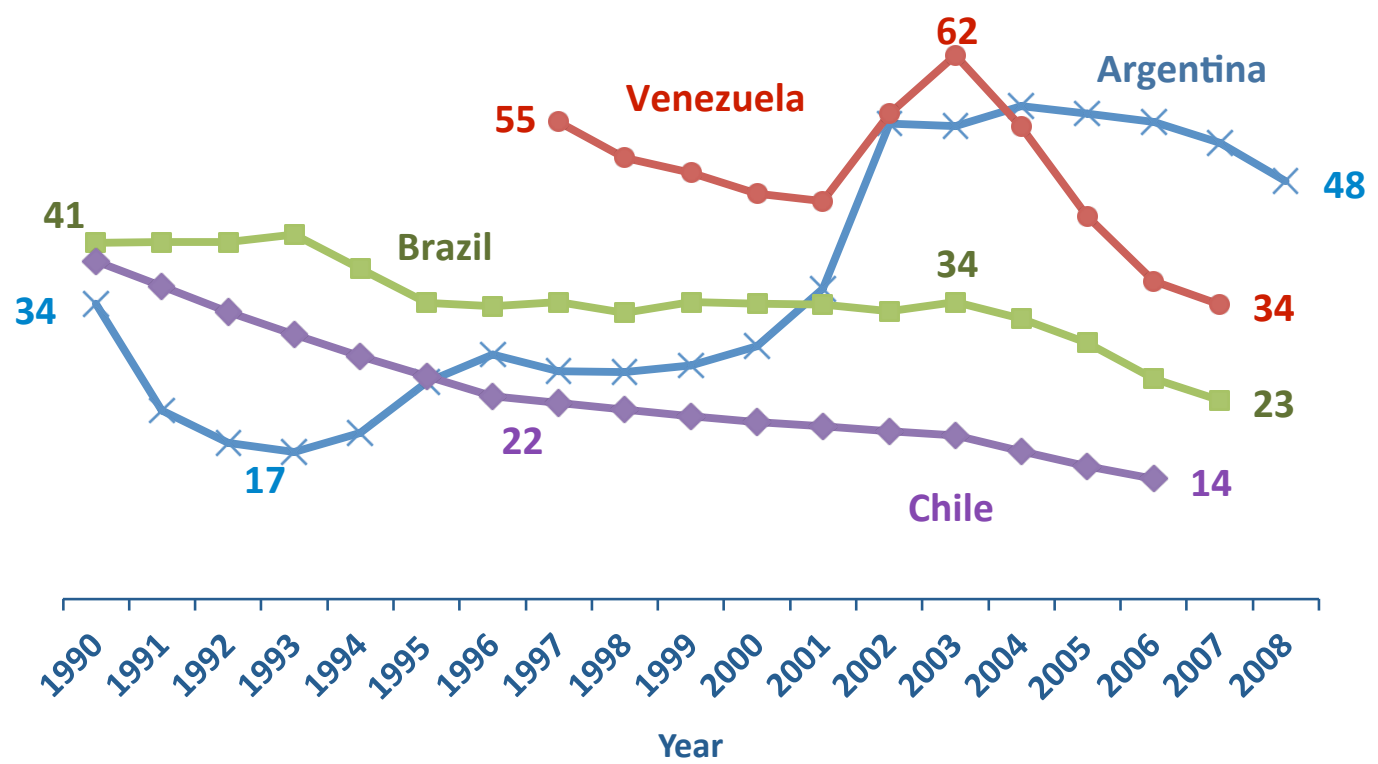

Source: SEDLAC/CEDLAS World Bank downloaded July, 2009. Argentina urban areas only. 
Figure 5b: Net Barter Terms of Trade

Population weighted average (1998=100)
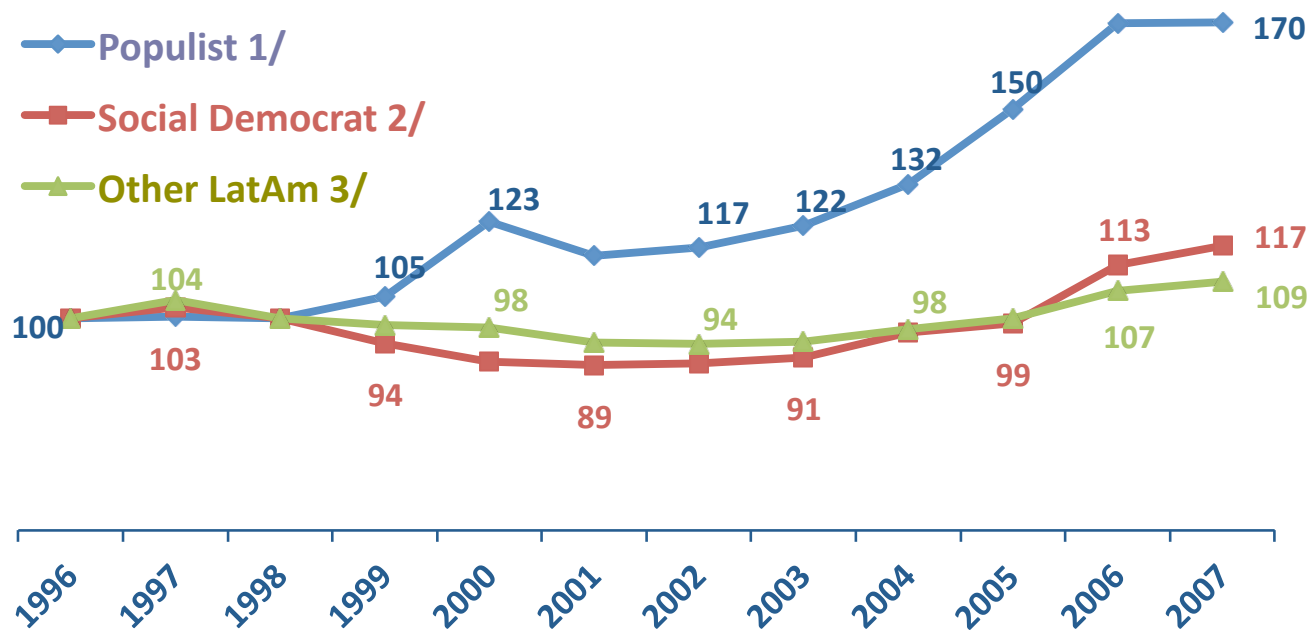

Source: World Bank, WDI online: 1/Argentina, Bolivia, Venezuela 2/Chile, Brazil, Uruguay

3/ Colombia, Costa Rica, El Salvador, Honduras, Mexico, Panama, Paraguay, Peru, Dominician Republic.

Figure 6: International \$PPP Population Weighted Poverty Rates for Latin America

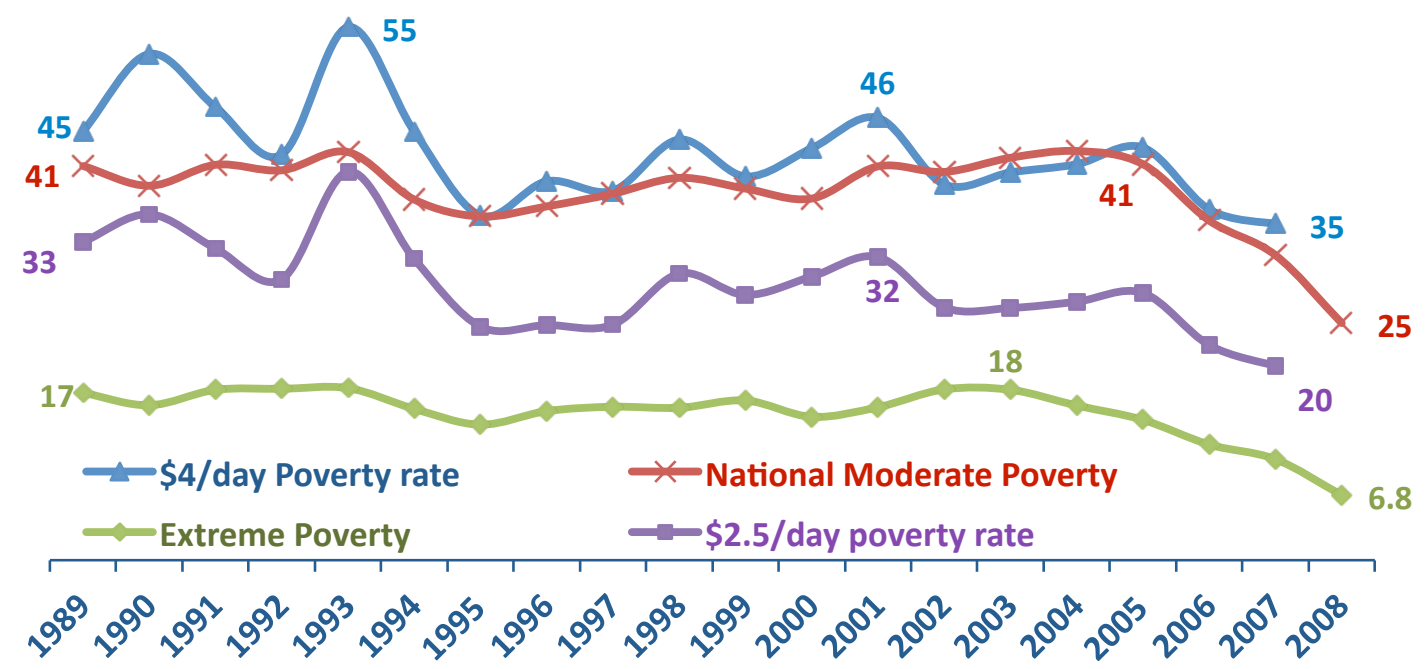

Source: SEDLAC/CEDLAS World Bank, author's calculation of weighted average poverty rates. 
${ }^{1}$ With a Gini coefficient of .53 (circa 2005), Latin America is 19 percent more unequal than Sub-Saharan Africa, 37 percent more unequal than East Asia and 65 percent more unequal than developed countries (Lopez-Calva and Lustig, 2010).

${ }^{2}$ Lopez-Calva and Lustig (2010) and the contributors to the volume Declining Inequality in Latin America: A Decade of Progress? report evidence of significant declines in inequality since 2000. Robinson (2010) argues that both the expansion of education and the increase in transfers targeted to the poor are a result of democratization. One implication of this recent sharp drop in extreme poverty is that Latin America appears to be back on track to meet its MDG goals (in fact, using the indigence or extreme poverty line closest to $\$ 1.25 /$ day it already has reached its goal (see Figures 2 and 6)). Exceptions to these trends are Uruguay and Nicaragua where inequality rose a little or where the reduction in inequality is not statistically significant. ${ }^{3}$ The "left populist" vs. social democratic classification is due to Arnson and Perales (2007) who in turn draw on the definition of populism outlined in Roberts (1995). He describes a number of characteristics of populist regimes including charismatic leadership that uses "widespread redistributive or clientelistic methods to create a material foundation for popular support."

${ }^{4}$ In some regressions, Uruguay is left out because its presence drives the results. Generally, however, our main results hold whether Uruguay is included or not.

${ }^{5}$ We prefer to use SEDLAC's data over CEPAL's because the latter corrects for under-reporting, a practice that is subject to controversy. Also, we prefer SEDLAC's over the WB data base (World Development Indicators) and WIDER's WIID2c because SEDLAC uses as consistent a methodology as available survey data permit and all data points come directly from surveys (i.e., there are no interpolations).

${ }^{6}$ Minimum wages tend to increase moderate poverty and have no impact on extreme poverty, as measured by the headcount ratio. Although Lustig and McLeod (1997) found that an increase in the minimum wage reduced extreme poverty, the impact depends on which effect dominates: the income increasing or the employment decreasing effect of higher minimum wages.

${ }^{7}$ This data is generally available online at http://www.depeco.econo.unlp.edu.ar/cedlas/sedlac/H.

${ }^{8}$ Appendix Tables A-6 and A-7 in Lustig (2009) show survey based inequality and poverty estimates for 18 Latin American countries and the Dominican Republic, as downloaded in June 2009. For the period 1989 to 2008, there are 166 available surveys which cover just over 50 percent of the years for 18 countries. Sampling over three year intervals generates a panel covering the same period but with only about $20 \%$ of the inequality measures missing.

${ }^{9}$ Cornia, op. cit., takes a different approach to deal with intermittent survey data, using data from WIDER's WIID2c and the World Bank's WDI data base to fill in 120 missing annual observations, interpolating another 98 observations between years (leaving about 25 missing data years in the early 1990s). This approach has the advantage of producing a large annual panel with over 300 observations. Though our three year interval panel is smaller, all LHS variables are actual survey estimates prepared by SEDLAC staff using as consistent a methodology as available surveys permit. Since inequality as measured by the Gini coefficient changes slowly over time, three year averages on the RHS may remove short term variability not related to long term inequality trends.

${ }^{10}$ As in Lustig and McLeod (2009) and Cornia, op. cit.

${ }^{11}$ This suggests that these regime dummies are capturing the effect of government policies. Using Chile's social democratic government as an example, the Lagos government took office in March 2000, so the first regime measure would be 1,1,1 (using the dates shown in the last three 
columns of Table 1). The second method counts the years in power during each interval, so this regime indicator would be 2,3,3 for Chile. The last three columns of Table 1 report the third measure, 2, 5, 8 for the three intervals.

12 According to a January $17^{\text {th }} 2010$ BBC story on the Chilean election, "Socialist Ms. Bachelet... will leave office in March with a high approval rating as a result of policies to tackle poverty and use Chile's all-important copper exports to offset the effects of the global economic crisis," precisely what this paper is about (BBC online "Billionaire Pinera wins Chile presidential election" HUhttp://news.bbc.co.uk/2/hi/8464136.stmUH).

${ }^{13}$ The series on social spending is obtained from CEPAL.

${ }^{14}$ Lopez-Calva and Lustig, op. cit., find evidence that social spending became more progressive after 2000.

${ }^{15}$ See Collier and Goderis (2008) and Brollo et al. (2010). Total public spending and net barter terms of trade variables were obtained directly from the World Bank's World Development Indicators as downloaded June 2009. Social spending is from CEPAL, Gasto público social como porcentaje del producto interno bruto (PIB) available at HUwww.eclac.cl/estadisticas/UH. ${ }^{16}$ See Huber et al. (2008).

${ }^{17}$ In panel econometric terms, fixed effects ignore "between" and reflect only "within" sample variations in inequality and poverty. The actual fixed effects estimates from Table 2 regressions are provided in Table 3. Note that Chile and Brazil's Gini coefficients are about 2-7 percentage points higher than expected during the period under study as indicated by high positive country fixed effects (see Table 3). That is, compared to other Latin American countries and controlling for Table 2 RHS variables such as per capita income and terms of trade, Chile and Brazil had higher than expected inequality. Argentina and Venezuela, on the other hand, had lower than expected Gini coefficients (about 4 to 9 percentage points lower according to Table 3 fixed effects).

${ }^{18}$ SEDLAC stands for Socio-Economic Database for Latin America and the Caribbean (CEDLAS and World Bank). ${ }^{19}$ These results include Uruguay in the social democratic group; however, Panama and Guatemala have been excluded because they have very few extreme and moderate poverty rates, reducing the sample from 18 to 16 countries - again poverty rates are sampled from three year intervals, not averaged or estimated.

${ }^{20}$ Contrary to the results of Lustig and McLeod (1997) and Cornia (2010), raising real minimum wages increases moderate poverty but has no impact on extreme poverty, as one might expect if the very poor have little contact with formal labor markets. 